\title{
Organizational Learning in Public Tertiary Educational Institutions
}

\author{
Emmanuel Akanpaadgi \\ Bolgatanga Technical University
}

\begin{abstract}
The study sought to examine how public tertiary educational institutions in Ghana can make use of organizational learning in order to improve upon their performance. Although organizational learning has proven to be beneficial to some organizations, it is not being utilized by public tertiary educational institutions in Ghana. The phenomenological research methodology was used to describe the experiences of the researcher in relation to the subject. Secondary data was also reviewed and analysed. The study concluded that for public tertiary educational institutions in Ghana to benefit from organizational learning, they must fully embrace Information Communication Technology while appointing leaders who understand the need to adopt organizational learning as a means of encouraging teamwork.
\end{abstract}

Keywords: Organizational culture, knowledge, experience, learning-cycle

\section{INTRODUCTION}

Learning is very essential to the success of every organisation. According Stata (1989) Organisational learning is when knowledge is acquired through brainstorming, experiments and observation in order to find a solution to a problem. Alternatively, organizational learning is seen as a system of developing new ideas about a particular subject and applying the experience acquired to similar situations whenever the need arises (Kane and Alavi, 2007). Learning, however, refers to the acquisition, retention and transmission of knowhow at the individual as well as team levels (Huber, 1991).

Continuous learning is required for organisations to survive and become competitive in a fast changing technological world (Nonaka \& Takeuchi, 1995). Organizations learn whenever they encounter problems and are able to find solutions to them through the marshaling of the scarce resources at their disposal such that if a similar one is faced in future it can apply that knowhow to solve it.

One of the factors that accounted for the good performance of the automobile industry in Japan was the fact that it was successful at continuous improvement and innovation through organizational learning (Nonaka \& Takeuchi, 1995). Learning organisations are committed to a cycle of continuous improvement by persistently challenging the existing systems in order to find alternative and better ways of doing things. 
Despite the potential benefits that organizational learning has, public tertiary educational institutions in Ghana are yet to tap into this concept as a tool to develop their institutions. The objective of this research paper is therefore to find out how public tertiary educational institutions in Ghana can take advantage of organizational learning to become institutions of excellence.

\section{METHODOLOGY}

This study employed the phenomenological methodology. The phenomenological research methodology is used to describe the personal experience of the researcher as it relates to the subject of enquiry (Streubert and Carpenter, 1999). According to Brink and Wood (1998), it involves intuition, description and an analysis of the issues that arose. The researcher therefore relied upon personal experience and observations about the management of public tertiary educational institutions in Ghana after having worked in the environment for over twenty years. Furthermore, secondary data on organizational learning was reviewed; and the author captured his personal experience against the background literature on the subject.

\section{DISCUSSION}

Argyris and Schon (1978) presented two different models of organizational learning; single-loop and double-loop. According to them, the single-loop learning takes place at the operational level where staff identify problems in their scope of work and try to rectify them. The single-loop model of learning is inward looking in the sense that it is only concerned about the existing methods of operation, it does not look beyond it (Kim, 1997). This is what pertains in most public tertiary educational institutions in Ghana.

On the other hand, the double-loop learning model requires challenging the status quo in order to find different and better ways of doing things (Kim, 1997). This learning model is lacking in public tertiary educational institutions in Ghana as most Vice Chancellors do not want the status quo to be challenged especially if they drive some personal benefits from it. The single-loop and doubleloop learning models presented by Argyris and Schon (1978) are similar to Kim's (1997) operational and conceptual levels of organizational learning.

According to Kim (1997), the operational level of organizational learning deals with the "how of doing things" which refers to the rationale behind certain actions and inactions within an organisation; while the conceptual learning talks about "why certain things are done" which requires organizational restructuring in order to cope with a changing environment.

Information Technology (IT) and e-commerce create the right environment for individual and organizational learning through the provision of accurate, timely and quality information. The conceptual learning model for example would enable an e-business organisation to compare the performance of one department or business unit with another; while the operational learning model will enhance individual learning by allowing them to reach out to as many people as possible to gather information about a problem (Kane and Alavi, 2007). Learning can occur at the individual and team levels:

\section{Individual learning}

Individual learning entails learning to improve individual capability and create value for an organisation. For individual learning to be effective, individual employees must be given the 
opportunity to explore various techniques of doing things so as to acquire skills and experience for the development of the organization. It is important to combine individual learning with organizational learning because when individuals acquire knowledge, it remains with them and whenever they leave the organization they leave with their knowledge but with organizational learning, the knowledge would be passed onto the members of the entire organisation and would remain with the organization even if there is a mass exodus of staff in the organisation.

The danger with individual learning is that if there is labour turnover in the institution, that individual's knowledge is lost to the institution; whereas with team learning, the rest of the team will continue to share the knowledge with the rest of their colleagues (Kane and Alavi, 2007). A high labour turnover will have disastrous consequences for such institution since a great deal of knowledge and experience would be lost to the institution.

\section{Team learning}

Team learning entails members of an organisation working together to accomplish set targets or goals (Senge, 1990). Once consensus has been built, it unleashes individual talents to create synergy as a result of the cross-fertilization of ideas in finding appropriate solutions to problems which otherwise would have been very difficult to solve (Senge, 1990).

This can be likened to the concept of Thermodynamics which deals with how energy is generated, transmitted and dissipated (Bratianu \& Andriessen, 2008). According to them, when a hot metal comes into contact with a cold one, it releases heat to the cold one. Heat according to the second law of Thermodynamics flows from a body with higher temperature to a body with lower temperature (Bratianu \& Andriessen). In the same vain when people work as a team there will be sharing of knowledge, skills and experience among members of the team. Knowledge would move from the brilliant and talented members of the team to the less brilliant and talented ones.

If public tertiary educational institutions in Ghana adopt this approach, the learning cycle will be further strengthened and the institutions would be able to find quick solutions to problems that are being encountered thereby consolidating their current enviable reputation in the world.

The pace at which organizations learn from their problems is called the learning cycle (Kim, 1997). The learning cycle can be accelerated or completed much more quickly if institutions make use of Information Communication Technology (ICT).

\section{CONCLUSIONS AND RESULTS}

The discussion on organizational learning points to leadership since visionary leaders create an enabling organizational culture that makes room for institutional learning and the preservation of the knowledge gained (Plant, 2001). Empirical evidence suggests that leadership drives organizational learning (Plant, 2001). Therefore, for organizational learning to thrive in public tertiary educational institutions in Ghana, the leadership must drive the change. The Vice Chancellors must become the change agents and then bring all other staff on board. This calls for a careful selection of human capital with proven record and experience to drive the quest for organizational learning. Another important driver for organizational learning is Information Communication Technology (ICT). Organizations such as Amazon.com, eBay, and Alibaba.com used e-commerce technology to breakthrough (Plant, 2001). Even though the Government of Ghana has 
Akanpaadgi, E. (2020). Organizational Learning in Public Tertiary Educational Institutions. Archives of Business Research, 8(5). 165-168.

invested heavily in ICT infrastructure; many public tertiary educational institutions are yet to fully embrace ICT. The right leadership will adopt the appropriate organizational structure and technology which will encourage teamwork in research.

\section{References}

Argyris, C. and Schon, D. (1978). “Organizational learning: A theory of action perspective.” Reading, MA: AddisonWesley.

Brink, P. J. and Wood, M. J. (1998). Advanced Design in Nursing Research: Advancing the Humanistic Perspective. $2^{\text {nd }}$ ed. California: Sage Publications.

Bratianu, C. \& Andriessen, D. (2008). Knowledge as energy: A metaphorical analysis. Proceedings of the 9th European Conference on Knowledge Management, Southampton Solent University, 4-5 September 2008.

Garfield, M. J., Taylor, N. J., Dennis, A. R. and Satzinger, J. W. (2001). "Modifying paradigms: Individual differences, creativity techniques and exposure to ideas in group idea generation." Information Res. Vol. 12(3) pp. 322-333.

Huber, G. P. (1991). “Organisation learning: The contributing processes and the literatures.” Organizational Science. Vol. 2(1) pp. 88-115.

Kane, G. C. and Alavi, M. (2007). "Information technology and organizational learning: An investigation of exploration and exploitation process." Organizational Science. Vol. 18, No. 5 Sept-Oct. pp. 796-812.

Kim, D. H. (1997). Toward Learing Organisations: Integrating Total Quality Control and Systems Thinking. Pegasus Communication Inc.

Plant, R. (2001). Creating an Integrated E-Commerce Strategey. New Jersey: Pearson Education.

Nonaka , I. \& Takeuchi, H. (1995). The knowledge-creating company: How Japanese companies create the dynamics of innovation. New York: Oxford University Press.

Senge, P. (1990). The fifth discipline: The art and practice of the learning organisation. New York: Currency Doubleday. Stata, R. (1989). “Organizational learning: The key to management innovation.” Sloan Management Review, 30(3).

Streubert, H. and Carpenter, D. (1999). Qualitative Research in Nursing: Advancing the Humanistic Perspective. $2^{\text {nd }}$ Ed. Thousand Oaks: Sage Publications. 